\title{
Digitalisasi Wisata Halal Melalui Aplikasi Smartphone Dimasa Pendemi Covid-19
}

\author{
Lukmanul Hakim \\ UIN Walisongo Semarang \\ elhakim@walisongo.ac.id
}

\begin{tabular}{l}
\hline Article Info \\
\hline Article history: \\
Received 15 Mei 2021 \\
Accepted 25 Juni 2021 \\
Published 22 Juli 2021 \\
Page : 136 - 147 \\
\hline
\end{tabular}

Keyword:

Digital tourism

Halal Tourism

Digitalisasi Wisata Religi

Platform Digital Tourism

\begin{abstract}
The potential of Indonesian Halal Tourism is in great demand by foreign tourists, in the current Covid-19 period, one of the most visible influences is the internet. The Internet has become a liaison for the whole world in carrying out its activities. During the Covid-19 pandemic, a platform in the form of a digital application is needed that can load all destinations, from places, lodging, food, and facilities owned by tourist attractions that are labeled halal tourism to restore tourist visits. It aims to find out how to develop Halal Tourism Applications on Smart Phones (android/OS). This writing uses library research (library research), and is qualitative, descriptive analysis. The results of the discussion show that the Potential for Transforming Digitalization to an easy and efficient smartphone, strengthening digital infrastructure in the form of services and qualified human resources, increasing synergies between stakeholders that strengthen policies that are able to encourage the acceleration of digitalization, and branding halal tourism by conducting the "Halal Lifestyle Literacy Campaign". "
\end{abstract}

Potensi Wisata Halal Indonesian sangat diminati Wisatawan mancanegara, di masa Covid-19 saat ini, salah pengaruh paling bisa dilihat yaitu internet. Internet menjadi penghubung seluruh dunia dalam melakukan aktivitasnya Secara online menerima Informasi dunia pariwisata. Dimasa pendemi Covid19 diperlukannya sebuah platfrom berupa aplikasi digital yang dapat meтuat semua destinasi mulai dari tempat, penginapan, makanan, serta fasilitas yang dimiliki tempat wisata yang diberi lebel halal tourism untuk memulihkan kembali Kunjungan Wisata. hal Tersebut bertujuan untuk mengetahui bagaimana pengembangan Aplikasi halal Tourism di Smart Phone (android/OS). Penulisan ini menggunakan library research (penelitian kepustakaan), dan bersifat kualitatif, deskriptif analisis. Hasil pembahasan menunjukkan bahwa Potensi Transformasi Digitalisasi ke smartphone yang mudah dan efisien, Penguatan infrastruktur digital berupa layanan dan sumber daya manusia yang mumpuni, meningkatkan sinergi antar stikholder yang menguatkan kebiajakan yang mampu mendorong percepatan digitalisasi, dan branding wisata halal dengan melakukan Kampanye "Halal Lifestyle Literacy".

Copyright (C) 2021 Journal Of Islamic Management.

Editorial Office:

Program Studi Manajemen Dakwah, Fakultas Dakwah dan Komunikasi, UIN Sunan Ampel Surabaya.

Jl. Ahmad Yani 117 Surabaya, Jawa Timur, Indonesia.

Email: jim@uinsby.ac.id 


\section{Pendahuluan}

Kondisi sektor pariwisata halal saat ini sedang mengalami penurunan secara drastis karena dampak dari adanya Covid19. Dalam masa pandemi covid-19 ini masyarakat dihimbau untuk tetap berada dirumah serta mengurangi mobilitas membuat berkurangnya jumlah pengunjung baik wisatawan lokal maupun asing menyebabkan pendapatan pariwisata menurun. Untuk mampu bertahan dalam masa pandemi Covid-19 maka diperlukan adanya pengembangan platfrom berupa aplikasi digital wisata halal dalam menghadapi pandemic Covid-19 dalam memulihkan kembali sektor Pariwisata.

Masa Covid-19 saat ini, salah satu dampak yang paling bisa dilihat yaitu internet. Internet menjadi penghubung seluruh dunia dalam melakukan aktivitasnya Secara online menerima Informasi . Dunia pariwisata telah sangat terbantu dengan berkembangnya teknologi. Pelaku dan stakeholder pariwisata telah dengan mudah mempromosikan asetnya melalui mediamedia tersebut. Dengan hadirnya teknologi, harapan ke depan akan semakin banyak inovasi dan kreasi-kreasi yang dikembangkan untuk kemajuan pariwisata halal di tataran global. Untuk mempermudah dalam mencari tempat wisata halal di Indonesia diperlukannya sebuah platfrom berupa aplikasi digital yang dapat memuat semua destinasi mulai dari tempat, penginapan, makanan, serta fasilitas yang dimiliki tempat wisata yang diberi lebel halal tourism. Dalam platform

1 Wiwit Denny Fitriana, "DIGITALISASI KULINER DAN WISATA Halal Daerah Jombang Melalui Aplikasi ' Jombang Halal Tourism ' Wiwit aplikasi juga dilengkapi dengan peta perjalanan untuk memberikan informasi secara rinci jarak tempuh yang akan di lalui wisatawan. dengan hadirnya platform aplikasi halal tourism. Kehadiran teknologi informasi memunculkan banyak peluang usaha untuk memperkenalkan wisata halal. Faktanya, internet sangat berperan terhadap perubahan yang signifikan tersebut terutama pada proses transformasi bisnis ke arah digitalisasi. Kondisi ini memungkinkan adanya penurunan biaya interaksi, transformasi, dan juga meningkatkan jumlah pendapatan. Kegiatan interaksi menjadi lebih mudah karena tidak perlu hadir secara fisik atau secara langsung. Penerapan wisata halal di Indonesia masih tergolong rendah dan membutuhkan sosialisasi lebih untuk memperkenalkan wisata halal ${ }^{1}$.

Dari beberapa penelitian tersebut belum ada yang membahas digitalisasi wisata halal melalui aplikasi smartphone dimasa pendemi covid-19. Penelitian ini berusaha mengetahui bagaimana pengembangan Aplikasi halal Tourism di Smart Phone (android/OS).

\section{Kajian Pustaka}

\section{A. Halal Tourism}

Terminologi Halal Tourism masih belum memiliki batasan yang jelas dalam mendefinisikan. Dan masih menggunakan beberapa nama yang cukup beragam diantaranya Halal Tourism, Islamic Tourism, Wisata Syari'ah, Wisata Religi, Halal Friendly Tourism Destination, Halal

Denny Fitriana Universitas Pesantren Tinggi Darul Ulum” 6, no. November (2018): 153-158. 
Travel, Muslim-Friendly Travel Destinations, halal lifestyle, dan lain-lain.

Halal Tourism di Indonesia merupakan salah satu program prioritas dari Kementerian Pariwisata. Pariwisata halal di Indonesia memiliki prospek ekonomi yang baik sebagai bagian dari industri pariwisata nasional dalam menghadapi berbagai tantangan di era industri 4.0. Industri wisata ini bertujuan bukan hanya memberikan aspek material, spiritual dan psikologis bagi wisatawan itu sendiri, melainkan juga memiliki kontribusi dalam peningkatan pendapatan pemerintah. Konsep wisata syariah menekankan prinsip-prinsip syari'ah dalam pengelolaan pariwisata, pelayanan yang santun dan ramah bagi seluruh wisatawan dan lingkungan sekitarnya. Dalam prakteknya wisata syariah memilih destinasi wisata yang menjunjung tinggi kaidah syariah Islam dan ini menjadi pertimbangan utama. Setiap destinasi wisata syariah di seluruh Indonesia yang akan menjadi tujuan harus sesuai dengan kaidah-kaidah keislaman ${ }^{2}$ secara Bahasa Halal Tourism ${ }^{3}$ Penjelasan gambar 1. Menurut Para Ahli dapat di definisikan Sebagai Berikut :

1. Wisata Religi (Religious Tourism) adalah wisata yang didasarkan pada

2 Kurnia Maulidi Noviantoro and Achmad Zurohman, "Prospek Pariwisata Syariah (Halal Tourism): Sebuah Tantangan Di Era Revolusi Industri 4.0," Equilibrium: Jurnal Ekonomi Syariah 8, no. 2 (2020): 275

${ }^{3}$ Fatkurrahman, "Developing Yogyakarta's Halal Tourism Potential for Strengthening Islamic Economy in Indonesia," Afkaruna: Indonesian Interdisciplinary Journal of Islamic Studies 13, no. 1 (2017).

${ }^{4}$ Wiwit Denny Fitriana, "Digitalisasi Kuliner Dan Wisata Halal Daerah Jombang Melalui Aplikasi ‘ nilai-nilai syariah Islam. Seperti yang dianjurkan oleh World Tourism Organization (WTO), konsumen wisata halal bukan hanya umat Muslim tetapi juga non Muslim yang ingin menikmati kearifan lokal ${ }^{4}$.

2. Wisata halal adalah menekankan prinsip syariah dalam pengelolaan wisata dan pelayanan yang santun dan ramah kepada seluruh wisatawan dan lingkungan sekitarnya. Oleh karena itu, menjadikan Indonesia sebagai pusat dunia syari'ah dalam pengelolaan dan pelayanan pariwisata yang santun dan ramah kepada seluruh wisatawan dan lingkungan sekitarnya ${ }^{5}$.

3. Wisata halal adalah destinasi yang menyediakan fasilitas dan layanan pariwisata halal sesuai dengan kebutuhan wisatawan muslim dan syariat Islam ${ }^{6}$. Wisata halal muncul dari kebutuhan wisatawan muslim sesuai ajaran Islam yakni sesuai dengan Al-Quran dan Hadits. Sehingga, Konsep wisata halal merupakan aktualisasi dari konsep ke-Islaman yakni nilai halal dan haram menjadi tolak ukur utamanya ${ }^{7}$.

4. Wisata Syari'ah (Syari'ah Tourism) adalah pemahaman makna halal disegala aspek kegiatan wisata mulai

Jombang Halal Tourism ' Wiwit Denny Fitriana Universitas Pesantren Tinggi Darul Ulum."

5 Aan Jaelani, "Halal Tourism Industry in Indonesia: Potential and Prospects," SSRN Electronic Journal, no. 76235 (2017).

6 Elpa Hermawan, "Strategi Kementerian Pariwisata Indonesia Dalam Meningkatkan Branding Wisata Halal," Jurnal Ilmu Manajemen dan Akuntansi 7, no. 2 (2019): 87-95.

${ }^{7}$ Eka Dewi Satriana and Hayuun Durrotul Faridah, "Halal Tourism: Development, Chance and Challenge," Journal of Halal Product and Research 1, no. 2 (2018): 32. 
dari hotel, sarana transportasi, sarana makanan dan minuman, sistem keuangan, hingga fasilitas dan penyedia jasa wisata itu sendiri. Sebagai contoh hotel Syariah tidak akan menerima pasangan tamu yang akan menginap jika tamu tersebut merupakan pasangan yang bukan muhrimnya (tidak dapat menunjukkan surat nikah) selain itu hotel yang mengusung konsep Syariah tentunya tidak akan menjual minuman beralkohol serta makanan yang mengandung daging babi yang diharamkan didalam Islam ${ }^{8}$.

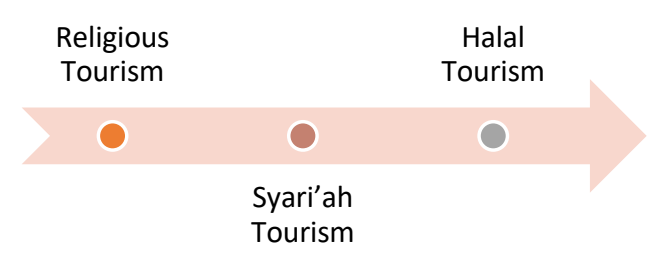

Gambar 1. Perkembangan Halal Tourism

Dari pandangan halal tourism diatas bisa kita definisikan bahwa halal tourism merupakn sebuah sistem pariwisata yang pelaksanaanya mematuhi aturan Syariah Islam.

\section{B. Digital Halal Tourism}

Smartphone adalah telepon seluler pintar yang mempunyai kemampuan tingkat tinggi dengan fungsi yang menyerupai komputer mini. Smartphone seakan menjadi perangkat yang wajib dimiliki oleh orang-orang dengan mobilitas tinggi yang ingin

\footnotetext{
${ }^{8}$ Wiwit Denny Fitriana, "Digitalisasi Kuliner Dan Wisata Halal Daerah Jombang Melalui Aplikasi ‘ Jombang Halal Tourism ' Wiwit Denny Fitriana Universitas Pesantren Tinggi Darul Ulum."
}

mengoptimalkan aktivitasnya demi meningkatkan produktivitas mereka. Salah satu Sistem Operasi yang digunakan pada Smartphone adalah Android. Android adalah sistem operasi milik Google ini memiliki perkembangan yang sangat cepat di pasaran. Pasar pengguna smartphone berbasis android meningkat secara signifikan dalam beberapa tahun terakhir (Testiana 2016).

Teknologi digital semakin canggih menyebabkan terjadinya perubahan penggunaan informasi digital semakin gencar. Teknologi memudahkan dalam melalukan akses terhadap informasi melalui banyak cara, serta dapat menikmati semua fasilitas dari teknologi digital dengan bebas, namun dampak negatif muncul pula sebagai mengancam. Pengembangan berbagai aplikasi merebak seiring diproduksinya ponsel pintar dengan operating system (OS) yang semakin mendekatkan diri pada kehidupan manusia yang ditujukan demi kemudahan dan kenyamanan penggunanya. Perkembangan OS juga merambah kepada peralatan digital lain seperti televisi pintar, mesin cuci pintar, kaca mata pintar, mesin pembuat kopi pintar, pengatur denyut jantung pintar, dan lain sebagainya ${ }^{9}$

\section{Perkembangan Halal Tourism}

Menurut Prof. Dr. Winai Dahlan, pendiri Halal Science Center di Universitas Chulalongkorn, Thailand Perkembangan Halal Tourism (Gambar 2). Teknologi 1.0, hanya ulama yang mengajarkan ilmu fikih (hukum atau

\footnotetext{
9 Wawan Setiawan, "Era Digital Dan Tantangannya," Seminar Nasional Pendidikan (2017): 1-9.
} 
aturan), termasuk fikih muamalah yang menjelaskan aturan terkait kegiatan sosial dan ekonomi. Dalam teknologi 2.0, halal dikembangkan melalui sinergi para ulama pemerintah. Namun seiring berjalannya waktu, ditemukan bahwa ulama dan pemerintah memerlukan para ilmuwan untuk melakukan riset dan pengembangan. Hal ini dikarenakan tidak semua orang dapat mengetahui detail suatu barang. Karena itulah hasil riset dan pengembangan menentukan proses kehalalan suatu produk yang tidak kasat mata, seperti bahan tambahan pada makanan. Dengan bersinerginya para ulama, pemerintah, dan ilmuwan, muncullah zaman baru yang dinamakan 3.0. Saat ini perkembangan telah mencapai zaman 4.0 sudah memiliki keterbukaan dan kemudahan informasi melalui teknologi sudah berkembang dengan pesat. Di zaman ini manusia tidak mungkin untuk tidak menggunakan teknolog. Dalam aspek halal, teknologi dimanfaatkan untuk komersial, penelusuran halal (treacibility), pemindaian halal (halal scan), dan masih banyak lagi.

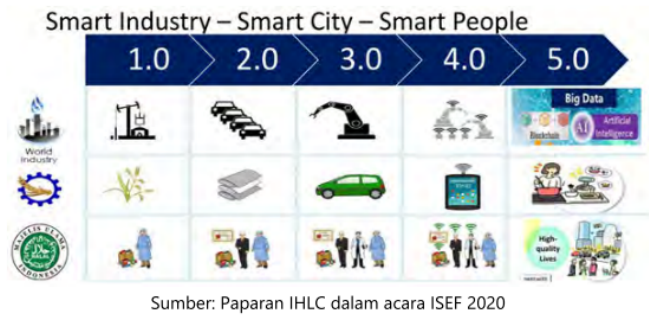

Gambar 2. Perkembangan Halal Tourism

Zaman 5.0 mengembangkan AI (Artificial Intelligence) dengan tujuan

${ }^{10}$ National Committee on Islamic Economic and Financial, "Halal Lifestyle To Improve The Quality Of Human Life," Insight, 2020. mempermudah kehidupan manusia nanti, manusia dan teknologi tidak bisa terpisahkan ${ }^{10}$

\section{Metode Penelitian}

Penelitian ini menggunakan metode kualitatif, melalui pengumpualan kajian pustaka dan dokumen yang diperoleh dari beberapa sumber lain seperti jurnal, majalah ataupun berita yang berguna untuk meningkatkan pemahaman terhadap data yang diperoleh. Studi kepustakaan adalah penelitian yang dilakukan dengan cara mengumpulkan, membaca, dan menganalisis sumber-sumber bacaan yang berhubungan dengan permasalahan objek kajian penelitian secara mendetail.

\section{Hasil dan Pembahasan}

Peningkatan wisatawan muslim dari tahun ke tahun merupakan peluang dan tantangan bagi sektor pariwisata untuk mengembangkan wisata halal. Banyak negara-negara (baik mayoritas muslim maupun non-muslim) berupaya mengembangkan wisata halal. Namun, dilihat dari konsep dan prinsip wisata halal yang ada, negara-negara tersebut umumnya hanya mencoba menciptakan suasana yang ramah muslim ${ }^{11}$.

Digitalisasi telah mengubah dan melakukan transfigurasi teknologi media dan komunikasi. Jaringan telepon otomatis yang sebelumnya dioperasikan secara manual sekarang bisa dioperasikan oleh perangkat jaring-intelek komputer dengan perangkat lunak yang mampu mengkonfigurasikan jaringan cerdas

11 Satriana and Faridah, "Halal Tourism: Development, Chance and Challenge." 
(intelligent network) dengan fitur-fitur kompleks digital ${ }^{12}$.

Pada Tahun 2019, Indonesia dinobatkan menjadi destinasi wisata halal terbaik dunia Oleh Global Muslim Travel Index (GMTI). Industri pariwisata halal di Indonesia secara umum memiliki kekuatan peluang yang cukup baik. Hal ini dibuktikan dari penghargaan-penghargaan yang diperoleh. Meskipun demikian, Indonesia perlu memperbaiki kekurangan dan menjawab tantangan yang dihadapi berupa sumberdaya manusia yang masih lemah, khususnya dalam penguasaan bahasa asing, regulasi yang belum memiliki induk undang-undang tertinggi, pemanfaatan teknologi yang masih rendah, belum masifnya sertifikasi halal, dan infrastruktur yang masih terbatas. Industri pariwisata halal tidak bisa dipisahkan dari industri pendukungnyayang terdiri dari destinasi pariwisata, alat transportasi, hotel dan akomodasi, restoran dan kafe, serta travel and tours (Tabel 1). Pedoman penyelenggaraan pariwisata berdasarkan prinsip Syariah terdapat padan Fatwa DSN Nomor 108 Tahun 2016. Isinya salah satunya mengatur ketentuan biro perjalanan wisata syariah wajib memiliki kompetensi kerja sesuai standar profesi yang dibuktikan dengan sertifikat. Juga berpenampilan sopan dan menarik sesuai prinsip syariah ${ }^{13}$.

Tabel 1. Nilai Rantai Industri Pariwisata

12 A G Eka and Wenats Wuryanta, "Digitalisasi Masyarakat: Menilik Kekuatan Dan Kelemahan Dinamika Era Informasi Digital Dan Masyarakat Informasi," Jurnal Ilmu Komunikasi (2013): 131142.

${ }^{13}$ Sukoso et al., Ekosistem Industri Halal, ed. Asep A. Prihanto, Muhamad Irfan Sukarna, and Hartono

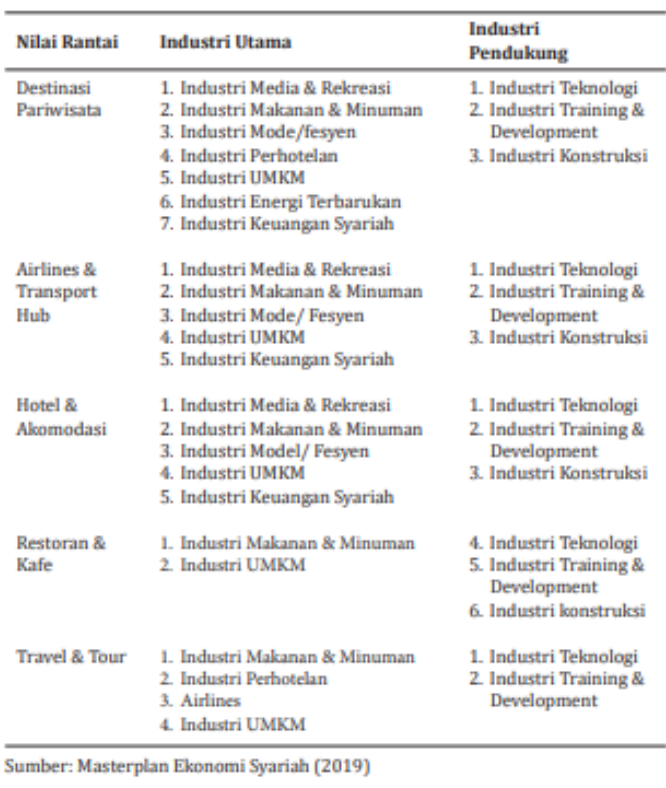

Peluang Pariwisata Halal yang Sangat Potensial

Industri pariwisata halal tidak bisa dipisahkan dari industri pendukungnya yang saling berkaitan. Beberapa nilai pariwisata halal yang terdiri dari desinasi pariwisata, alat transportasi, hotel dan akomodasi, restoran dan kafe, serta travel and tours. Berikut adalah ilustrasi rantai nilai industri pariwisata halal yang menggambarkan proses dan hubungan setiap entry point beserta ekosistem pendukungnya pada gambar 2 .

Harimurti, Departemen Ekonomi Dan Keuangan Syariah - Bank Indonesia (Jakarta: Departemen Ekonomi dan Keuangan Syariah - Bank Indonesia Pusat Studi Halal Thoyyib - Universitas Brawijaya, 2020). 


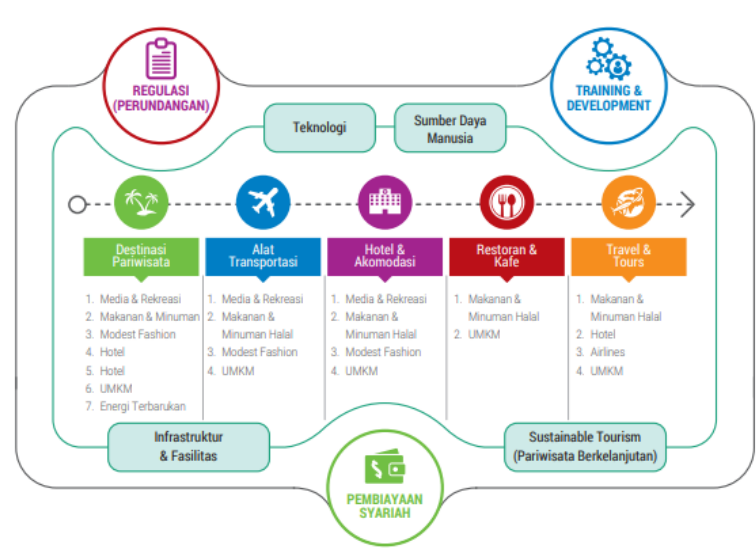

Gambar 3. Rantai Nilai Industri Pariwisata Halal

Pengembangan Aplikasi di smartphone membuat sebuah transformasi digital di sector wisata halal Indonesia yang semakin menarik didunia. pembuatan aplikasi di android maupun OS menjadi sangat menarik untuk dikembangkan . aplikasi wisata halal khususnya bidang religi berbasis android yang dapat memudahkan para wisatawan untuk mengakses informasi pariwisata halal dengan penggunakan metode User Centered Design yang berfokus pada kebutuhan fungsional dan non fungsional pengguna sistem ${ }^{14}$.

Pengembangan Halal Tourism yang sudah dikembangkan menggunakan Aplikasi Android

1. Jombang Halal Tourism

Aplikasi "Jombang Halal Tourism" yang berisikan informasi mengenai fasilitas, harga dan info mengenai wisata yang syariah. Dengan adanya aplikasi ini diharapkan dapat

14 Chandra Sukma Anugrah, Harry Budi Santoso, and Indra Budi, "Rancang Bangun Aplikasi Wisata Halal Berbasis Android Menggunakan Metode User Centered Design," Seminar Nasional Aptikom (Semnastik) 2019 (2019): 314-321. meningkatkan nilai Pariwisata Jombang ${ }^{15}$.

2. DeRe Semarang

DeRe merupakan sebuah aplikasi destinasi religious yang ada di Semarang. Aplikasi ini membantu mempermudah wisatawan yang akan berkunjung ketempat wisata religi yang ada di daerah Semarang. Adapun aplikasi ini memudahkan wisatawan untuk tidak hanya menemukan jalan mereka di sekitar semarang, tetapi untuk memudahkan mencari penginapan halal, kuliner halal, oleh-oleh, dan tempat beribadah masjid atau mushola.

3. Halal Local

Halal Local, sebuah aplikasi marketplace yang menghadirkan informasi restoran halal, tempat ibadah, akomodasi, dan pemandu wisata ramah Muslim bisa menjadi jawaban. halal Local berfungsi untuk mencari lokasi masjid atau musala terdekat, lokasi restoran yang menyajikan makanan halal dan bisa memesan makanannya langsung, lokasi penginapan ramah Muslim serta dapat memesan penginapannya, lokasi tempat wisata ramah Muslim dan dapat membeli tiket masuk tempat wisata tersebut, serta memesan trip wisata halal, umrah, dan haji. memiliki mitra 40.000 daftar dari restoran halal, hotel,Trip Wisata Halal, Masjid, homestay, dan Badan halal di Negara-negara Asia Tenggara.

\section{A. Go Digital Halal Tourism}

\footnotetext{
${ }^{15}$ Wiwit Denny Fitriana, "Digitalisasi Kuliner Dan Wisata Halal Daerah Jombang Melalui Aplikasi ‘ Jombang Halal Tourism ' Wiwit Denny Fitriana Universitas Pesantren Tinggi Darul Ulum."
} 
Potensi ini dapat dimanfaatkan oleh negara Indonesai agar selalu berusaha dalam meningkatkan serta mengembangkan pariwisata halal (halal tourism). Semangat Kementrian Pariwisata dalam memanfaatkan keadaan geostrategic Indonesia juga dapat menjadi pendukung untuk perkembangan pariwisata syari'ah Indonesia yang mana terdapat sekitar 13.677 pulau, 1.340 suku bangsa, 652 bahasa daerah yang berbeda dengan luas wilayah $1.906 .240 \mathrm{~km} 2$ terbentang dari sabang sampai merauke. Sehingga, Indonesia memiliki nilai plus untuk dijadikan sebagai negara tujuan wisata Halal ${ }^{16}$. Melihat Potensi wisata Indonesia pada gambar 3 mampu meningkatkan peluang kunjungan melalu aplikasi dan digitalisasi wisata secara langsung

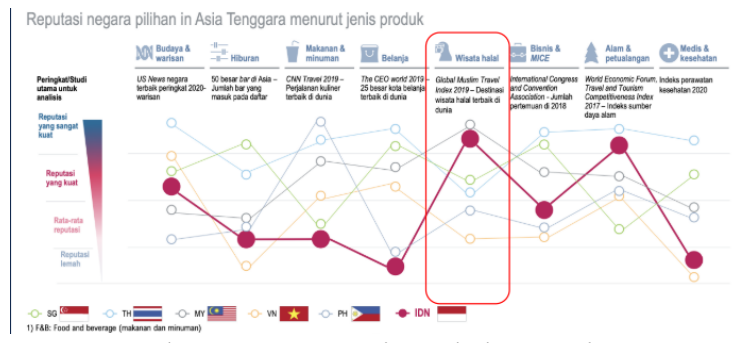

Gambar 4. Potensi Halal Tourism Indonesia

Pengembangan Halal Tourism dalam Meningkatkan Kunjungan di era industry halal 4.0 yaitu :

1. Kolaborasi antara pemangku kepentingan sektor publik dan swasta untuk mengkonsolidasikan dan menyatukan standar sertifikasi halal secara nasional \& global.

2. Optimalisasi teknologi untuk mendukung pengembangan industri

\footnotetext{
${ }^{16}$ Noviantoro and Zurohman, "Prospek Pariwisata Syariah (Halal Tourism): Sebuah Tantangan Di Era Revolusi Industri 4.0."

17 Salman Dianda Anwar, "Pengembangan Pariwisata Halal DKI Jakarta Berbasis Digital" (2019).
}

halal; pencari makanan dan restoran halal, pendeteksi bahan ${ }^{17}$.

3. Branding kini menjadi bagian penting dalam strategi pemasaran suatu destinasi. Diketahui bahwa branding menjadi alat untuk memasarkan suatu produk atau pelayanan. Branding digambarkan sebagai strategi melalui nama, istilah, tanda, simbol atau kombinasinya dalam menarik minat konsumen atau menggunakan produk. Seperti yang dilakukan oleh Kementerian Pariwisata Indonesia untuk menjadikan Indonesia sebagai salah satu terbaik di dunia dalam penyediaan layanan wisata $^{18}$. Pariwisata Halal Indonesia telah memiliki logo yang merupakan turunan dari identitas visual brand pariwisata Indonesia.Branding Pariwisata Halal Indonesia dapat Dilihat Gambar 4.

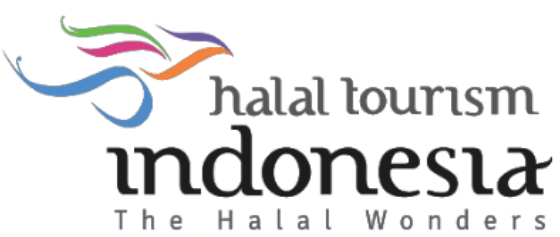

Gambar 5. Branding Pariwisata Halal Indonesia

Branding halal tourism di Indonesia memang belum terlalu moncer sehingga tak banyak wisatawan lokal dan mancanegara yang mengetahui brand tersebut. Oleh karenanya, penggunaan teknologi adalah sebuah keharusan di era industri ini. Pemerintah perlu bekerjasama dengan masyarakat khususnya generasi muda yang melek teknologi, untuk mempromosikan Potensi halal Tourism

\footnotetext{
18 Hermawan, "Strategi Kementerian Pariwisata Indonesia Dalam Meningkatkan Branding Wisata Halal."
} 
Indonesia ${ }^{19}$. Pengembangan Potensi wisata halal yang dikembangkan kementrian pariwisata dan ekonomi kreatif bisa dilihat pada gambar 5. hal tersebut menunjukan bahwa digitalisasi melalui Aplikasi Android dan OS sangat potensial dikembangkan.

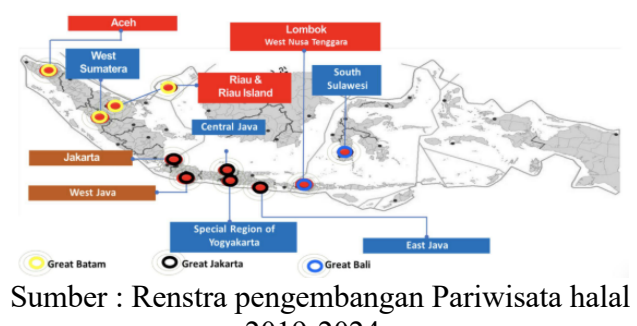
2019-2024

Gambar 6. Potensi Wisata Halal ndonesia

Pengembangan Aplikasi halal Tourism di Smart Phone (android/OS) Indonesia Perlu dilakuan :

1. Pengembangkan Aplikasi yang mudah di akses .

2. Literasi pengusaha dan masyarakat dalam mengembangkan gaya Hidup halal

Literasi untuk para pengusaha adalah terpusat pada peluang bisnis di bidang halal. Belum banyak pengusaha yang berani terjun langsung di bidang ini. Hal ini terlihat dari masih sedikitnya hotel syariah di Indonesia jika dibandingkan dengan hotel syariah di Thailand yang merupakan Negara yang penduduk muslimnya adalah minoritas. Saat ini hotel syariah di Indonesia yang besar hanya dapat dihitung dengan jari. Sedangkan hotel bintang 3 sampai 5 di Thailand jumlahnya bisa 2 kali lipat hotel syariah besar di Indonesia.

Adapun literasi masyarakat juga perlu ditingkatkan. Indonesia yang

${ }^{19} \mathrm{~K}$ Muhajarah and L Hakim, "Promoting Halal Tourism: Penggunaan Digital Marketing Communication Dalam Pengembangan Destinasi Wisata Masjid," Al-Muttaqin: Jurnal Studi, Sosial, dan ... 02, no. 01 (2021): 34-42, penduduknya mayoritas beragama Islam ternyata masih memiliki tingkat kesadaran halal yang rendah. Hal ini tercermin dari adanya persepsi apabila penjual atau pramusaji menggunakan identitas keislaman seperti kopiyah atau hijab, maka mustahil menjual produk nonhalal. Padahal halal bukan hanya dari zat benda saja, yang tidak mudah dilihat dengan kasat mata seperti zat aditif (penyedap, pewarna, pengental dan lainnya) untuk produk makanan dan makanan olahan demikian juga dari keseluruhan proses produksidari hulu ke hilir ${ }^{20}$.

3. Pengembangan Gaya hidup halal merupakan pasar potensial, yang harus direspon dengan menyediakan produk dan jasa dengan nilai-nilai islami (spiritual benefit) melalui pemanfaatan media digital. Akibat adanya pembatasan aktivitas fisik masyarakat, tingkat konsumsi penggunaan aplikasi, game, dan media digital lainnya meningkat secara signifikan. Hal ini perlu dimanfaatkan secara maksimal. Konten terkait ekonomi dan keuangan syariah tentunya dapat dimasukan ke dalam berbagai platform digital, seperti aplikasi, game, film, dan lain sebagainya. contoh : fesyen muslim, berbagai produk kini ditampilkan di platform e-commerce. Selain itu, saat ini sudah banyak dilakukan virtual peragaan busana yang memanfaatkan teknologi digital.

4. Penguatan Infrastruktur Digital

Peta infrastruktur wisata halal bagaimana disektor infrastruktur melakukan sebuah penguatan

http://staisam.ac.id/jurnal/index.php/almuttaqin/art icle/view/35.

${ }^{20}$ National Committee on Islamic Economic and Financial, "Halal Lifestyle To Improve The Quality Of Human Life." 
a. Logistik halal merupakan suatu proses mengelola pengadaan, pergerakan, penyimpanan, dan penanganan materialdan persediaan barang setengah jadi baik makanan dan bukan makanan bersama dengan informasi terkait dan aliran dokumentasi melalui organisasi perusahaan dan rantai pasok yang patuh terhadap prinsipprinsip umum syariah.

b. Sistem telusur

Sistem Telusur atau traceability sistem merupakan kemampuan untuk menyajikan informasi yang berkaitan dengan riwayat dan perpindahan barang/ benda melalui setiap tahapan proses produksi hingga distribusinya. Proses sistem telusur halal mengikuti mekanisme system development life cycle (SDLC), meliputi requirement analysis, design and development, testing and evaluation.

c. Riset dan pengembangan

Hasil dari riset dan pengembangan bidang ekonomi Islam dapat membantu industri dalam memenuhi kebutuhan pasar atas produk barang dan jasa halal. Selain itu, riset dan pengembangan juga dapat berkontribusi untuk meningkatkan efisiensi industri sehingga memotong biaya ekonomi halal. Indonesia memiliki beberapa lembaga penguji untuk riset dan pengembangan halal yang berlisensi dan bersertifikat, contohnya PT Sucofindo, PT Saraswanti Indo Genetech, dll. PT Sucofindo merupakan salah satu institusi Badan Usaha Milik Negara (BUMN) yang merupakan mitra dari BPJPH yang mempunyai kemampuan teknologi untuk inspeksi, sertifikasi, dan pengujian halal. Uji yang dapat dilakukan misalnya, Porcine Test, Kromatografi, Polymerase Chain Reaction (PCR), dll.

d. Standarisasi dan sertifikasi Standarisasi halal bertujuan untuk memberikan keamanan untuk konsumennya. Halal ditetapkan berdasarkan sumber dari Al Quran dan As Sunnah, dan kajian ilmiah yang berdasarkan pada hukum Islam. sedangkan Sertifikasi Halal pada produk dan jasa bertujuan untuk memberikan kepastian hukum terhadap status kehalalan, sehingga dapat menenteramkan batin konsumen dalam mengkonsumsinya. esinambungan proses produksi halal dijamin oleh produsen dengan cara menerapkan Sistem

Jaminan Produk Halal.

5. Branding Wisata halal dengan melakukan Kampanye "Halal Lifestyle Literacy".

Keberhasilan destination branding dan diplomasi publik Indonesia sebagai destinasi wisata halal dapat dilihat dari peringkat Indonesia menjadi peringkat pertama dengan nilai 78 sebagai destinasi wisata halal terbaik dunia berdasarkan Global Travel Index 2019 yang memperhatikan aksesibilitas, lingkungan, komunikasi dan layanan (MasterCard; CrescentRating, 2019). Pada tahun 2017 peringkat ketiga dengan nilai 72,6 (MasterCard; CrescentRating, 2017). Sedangkan tahun 2018 berada di peringkat kedua dengan nilai 72.8 (Mastercard \& CrescentRating, 2018). Ini menunjukkan kemajuan dalam 
pembangunan pariwisata halal di Indonesia ${ }^{21}$.

6. Penguatan SDM dalam meningkatkan halal tourism.

Manajemen sumber daya manusia akan mempunyai peranan dalam meningkatkan keefektifan dan efisiensi sebuah perusahaan. SDM Merupakan aspek yang mendasar yang perlu ditingkatkan SDM tersebut adalah,pemandu wisata, auditor, penyelia, dan juru sembelih halal. Selain peningkatan kompetensi SDM, Pendidikan dan pelatihanbserta training untuk menyiapkan SDM sadar halal juga tidak kalah pentingnya.

Digitalisasi Wisata Halal Melalui Aplikasi Smartphone di Masa Covid-19 perlu dilakukan ;

1. Promosi Wisata Halal yang dikemas dengan memberikan Promo/ Diskon setiap kali melakukan pembelian melalui aplikasi

2. Penguatan Branding Wisata Halal mengingkatkan minat berkunjung wisatawan .

3. Penguatan Infrastruktur digital dalam meningkatkan kunjungan.

4. Penguatan Sumber Daya Manusia di destinasi wisata halal yang menerapkan nilai-nilai keislaman.

5. Meningkatkan sinergi antar stikholder yang menguatkan kebiajakan yang mampu mendorong percepatan digitalisasi

6. Penguatan Literasi Digital yang mendukung pola peningkatan kunjungan secara bijak dan efisien.

21 Awafi Ridho Subarkah, Junita Budi Rachman, and Akim, "Destination Branding Indonesia Sebagai Destinasi Wisata Halal," Jurnal
Transformasi Perubahan yang dilakukan dalam digitalisasi sebuah wisata Halal Harus meliputi :

1. Administrasi pengunjung seperti; tiket masuk, retribusi, statistik pengunjung, yang mudah.

2. Sistem layanan wisata seperti; pemesanan tiket, koordinasi dengan biro perjalanan/biro wisata, koordinasidengan sistem perhotelan.

3. pembukuan sebuah kegiatan yang mudah

4. Akses yang mudah dan simple untuk digunakan.

\section{Kesimpulan}

Dari hasil kajian data disimpulkan bahwa digitalisasi wisata halal melalui aplikasi smartphone di masa pendemi covid19 yaitu : Transformasi Digitalisasi ke smartphone yang mudah dan efisien, Penguatan infrastruktur digital berupa layanan dan sumber daya manusia yang mumpuni, meningkatkan sinergi antar stikholder yang menguatkan kebiajakan yang mampu mendorong percepatan digitalisasi, dan branding wisata halal dengan melakukan Kampanye "Halal Lifestyle Literacy”.

\section{Daftar Pustaka}

Anugrah, Chandra Sukma, Harry Budi Santoso, and Indra Budi. "Rancang Bangun Aplikasi Wisata Halal Berbasis Android Menggunakan Metode User Centered Design." Seminar Nasional Aptikom (Semnastik) 2019 (2019): 314-321. Anwar, Salman Dianda. "Pengembangan

Kepariwisataan: Destinasi, Hospitalitas dan Perjalanan 4, no. 2 (2020): 84-97. 
Pariwisata Halal DKI Jakarta Berbasis Digital" (2019).

Eka, A G, and Wenats Wuryanta. "Digitalisasi Masyarakat: Menilik Kekuatan Dan Kelemahan Dinamika Era Informasi Digital Dan Masyarakat Informasi." Jurnal Ilmu Komunikasi (2013): 131-142.

Fatkurrahman. "Developing Yogyakarta's Halal Tourism Potential for Strengthening Islamic Economy in Indonesia." Afkaruna: Indonesian Interdisciplinary Journal of Islamic Studies 13, no. 1 (2017).

Hermawan, Elpa. "Strategi Kementerian Pariwisata Indonesia Dalam Meningkatkan Branding Wisata Halal." Jurnal Ilmu Manajemen dan Akuntansi 7, no. 2 (2019): 87-95.

Jaelani, Aan. "Halal Tourism Industry in Indonesia: Potential and Prospects." SSRN Electronic Journal, no. 76235 (2017).

Muhajarah, K, and L Hakim. "Promoting Halal Tourism: Penggunaan Digital Marketing Communication Dalam Pengembangan Destinasi Wisata Masjid." Al-Muttaqin: Jurnal Studi, Sosial, dan ... 02, no. 01 (2021): 3442.

http://staisam.ac.id/jurnal/index.php/ almuttaqin/article/view/35.

National Committee on Islamic Economic and Financial. "Halal Lifestyle To Improve The Quality Of Human Life." Insight, 2020.

Noviantoro, Kurnia Maulidi, and Achmad Zurohman. "Prospek Pariwisata Syariah (Halal Tourism): Sebuah Tantangan Di Era Revolusi Industri 4.0." Equilibrium: Jurnal Ekonomi Syariah 8, no. 2 (2020): 275.

Satriana, Eka Dewi, and Hayuun Durrotul Faridah. "Halal Tourism: Development, Chance and Challenge." Journal of Halal Product and Research 1, no. 2 (2018): 32.

Setiawan, Wawan. "Era Digital Dan Tantangannya." Seminar Nasional Pendidikan (2017): 1-9.
Subarkah, Awafi Ridho, Junita Budi Rachman, and Akim. "Destination Branding Indonesia Sebagai Destinasi Wisata Halal." Jurnal Kepariwisataan: Destinasi, Hospitalitas dan Perjalanan 4, no. 2 (2020): 84-97.

Sukoso, Adam Wiryawan, Joni Kusnadi, and Sucipto. Ekosistem Industri Halal. Edited by Asep A. Prihanto, Muhamad Irfan Sukarna, and Hartono Harimurti. Departemen Ekonomi Dan Keuangan Syariah - Bank Indonesia. Jakarta: Departemen Ekonomi dan Keuangan Syariah - Bank Indonesia Pusat Studi Halal Thoyyib Universitas Brawijaya, 2020.

Wiwit Denny Fitriana. "Digitalisasi Kuliner Dan Wisata Halal Daerah Jombang Melalui Aplikasi ‘ Jombang Halal Tourism ' Wiwit Denny Fitriana Universitas Pesantren Tinggi Darul Ulum" 6, no. November (2018): 153158. 